British Journal of Chinese Studies, Vol. 10, July 2020

ISSN 2048-0601

(C) British Association for Chinese Studies

\title{
Zen and the "Image" in Tang Poetry
}

\section{T. H. Barrett}

SOAS, Emeritus

\begin{abstract}
Poetry based upon the presentation of a striking image has been familiar in English for over a century; in China it is much older, and in the second half of the eighth century it was already being discussed using the word jingjie 境界 or simply jing. While the Buddhist overtones of this term have been noted, the degree to which it was widely used in a discourse of meditation that stretched well beyond the scholastic works of the Buddhist clergy has not. Meditation as a source of unbidden images would seem to be part of a late eight century and early ninth century interest in the wellsprings of poetic creativity also manifest in discourse about intoxication and poetry. While there is no direct connection with Anglophone interest in Imagism, a possible indirect connection via Japanese and French may be worth investigating in the future.
\end{abstract}

Keywords: Ezra Pound, Imagism, Chan (Zen) and poetry, Wang Wei, meditation and poetry.

The purpose of the title of this piece is to suggest that behind the bland exterior of the average medieval Chinese poem (at least in English translation) there may lurk processes of composition entirely unsuspected by the modern reader, aspects of the Tang poem that might repay greater study. This approach - namely meditation as a method of creative inspiration - was far from universal in the poetry of the Tang period, since it seems to have arisen within specific historical circumstances, and though references to it remained and were handed down to later ages in widely read works, it is at present unclear how actively it was practised in later times. However, there is sufficient evidence to suggest that an interest in poetic imagery remained strong in East Asia, raising the possibility that it was this aspect of poetic practice there that caught the attention of English-language poets in the United Kingdom at the start of the twentieth century, as they cast about for new models to replace the poetry of Victorian times. The hope is that drawing attention to this approach to poetic inspiration in this essay may serve as a challenge to the current lack of interest in Chinese poetry translation in the United Kingdom.

Before we can delve into our observations, it is necessary to clarify the term "Zen." In China chan 禅 simply meant "meditation" and masters of meditation were not necessarily affiliated with the distinctive tradition that took this name, any more than all who baptise in Christian circles would claim to be Baptists. In the view of modern scholarship, the Zen tradition emerged only slowly in China: the eighth 


\section{2 | T. H. Barrett}

century certainly had a notion of certain lineages of meditation teachers who claimed to carry forward a non-verbalised heritage of insight stretching back to the Buddha, but the coherence of these lineages into a broader tradition seems to be more a feature of the ninth century. Meanwhile larger shifts were, during this span of time, taking place across the Chinese intellectual world as a whole, especially in the unsettled conditions following the near-collapse of the dynasty in the mid-eighth century. Broadly speaking, while in the two centuries before this shift many Chinese had conceptualised their culture as existing on two levels, one relating to indigenous traditions and another at a higher level reflecting the imported wisdom of Buddhism (Barrett, 2009), now there was a move towards intellectual integration in the face of a threatened political fragmentation, either by collapsing the higher level into the lower by declaring Buddhism redundant within China's culture, or by synthesising both levels of culture more closely. The phenomena discussed here fit readily into the second trend, though the basic insight underlying the developments discussed was no doubt well understood well before its implications for the composition of poetry started to be worked out, namely that unanticipated visionary experiences could be achieved by Buddhist meditative practice (Greene, 2016: 321). ${ }^{1}$ The language used to describe this may legitimately be termed "technical" (Greene, 2016: 322), but this should not lead us to ignore its importance or broad influence. One purpose of the following observations is to stress that the "technical" term involved was not by any means an abstruse one, but rather was one that - like many Buddhist elements in the language of the Tang regarded as difficult and exotic today - was very widely used and understood. No attempt is however made in this essay to situate this phenomenon within any broader discourse on Buddhism and Tang poetry. The aim is instead to present a fragment of this whole in the hope that it may pique the interest of others to delve further, or at least to start reading Tang poetry in the original with an eye to the many unexplored issues that it raises.

Much ink has of course already been spilled on the relationship of Chan Buddhism to poetry, but unfortunately from the point of view of the historian of religion not enough attention has been paid to evolving historical factors. To assume that every meditation master of the eighth century was a "Zennist" in the sense used later is unsafe, especially when even a monk who both wrote on poetry and associated himself with a lineage of Chan practitioners might also have other simultaneous interests, such as the study of Buddhist discipline (Nielson, 1972: 56). Describing any poetry written before a broader conception of what constituted the Chan tradition arose as in any sense "Zen" also seems problematic. Thus Nicholas Morrow Williams accepts the point of Jia Jinhua 賈晉華 that influence more likely flowed from an early eighth century poet to the reforming Chan masters of later in the century, but feels that it is still legitimate to discuss the former in terms of a Zen poetic, just as it is a valid hermeneutical venture to discuss a play by Shakespeare in Freudian terms (Williams, 2017: 34). True, but we are in a position to appreciate that, be it indirectly or by direct reading, Freud was for his part also a Shakespearian; until Jia's point is more widely understood such ventures tend to risk confusion.

\footnotetext{
${ }^{1}$ I was able to attend an earlier lecture in which Eric Greene outlined his findings on the question of how meditation was actually held to work in medieval China (see Greene, 2016), and the conception of meditation incorporated into my remarks doubtless reflect that influence, especially since I have no experience of meditation myself.
} 
In fact, there is at least one indication that, as the Chan tradition sought to define itself as a broad movement in the ninth century, it did try to incorporate at least one earlier poet, Wang Fanzhi 王梵志 (birth and death dates unknown) (Broughton, 2009: 177). But in the long run this numinous yet decidedly inelegant folk versifier proved too marginal to represent the Chan movement's literary ideals, and instead the more appropriate figure of Hanshan 寒山 was eventually co-opted to serve in the role of Zen poet. Even then it seems more likely that Zen underwent a touch of Hanshan than that the reverse happened (Hobson, 2003: 136). Rather than engage this broader but problematic field at all, the following remarks concentrate instead on the appearance of implicit and eventually explicit commendations of meditation as an aid to poetic composition, while acknowledging that though the relevant terminology was widespread enough to be seen as neither abstrusely technical nor as associated with only one school within East Asian Buddhism, the development within the unfolding of Tang literary history took place in the same context in which Chan Buddhism was also taking shape.

The following remarks, then, are simply designed to stimulate reflection and discussion rather than to provide a definitive solution to any research problem.

The idea in question here is that Buddhism, especially (even if not straightforwardly) of the type we now call "Zen," after its Japanese pronunciation, influenced the ways of looking at and discussing poetry that emerged in China in the eighth century. This influence seems to have been particularly strong in drawing attention to the visual aspects of poetry, and that is why the English term "Imagism" was initially deployed above in the title, rather than because of any particularly close analogy, let alone because of any as-yet-unverifiable direct historical link. But in so far as may be judged from our current state of knowledge, an indirect link, through Chinese influences on Japanese conceptions of poetic writing, and thence on through early Western ventures in writing new forms of poetry, is entirely possible.

Narratives of the history of Imagism in English-language poetry are numerous, but all are generally agreed on the key role of the aforementioned Ezra Pound, in part through his editorial promotion of others, but also in part thanks to his fourteen-word poem "In a Station of the Metro" (1911), which took him a solid year to write, as he pared it down and pared it down to its central image (Kenner, 1971: 184-7). Imagism as a movement came and went, but after the immense effort poured into this tiny poem the English poetic tradition was never the same again. Yet while one should not discount the classical influences exerted on Pound, and even more on his friends, the consensus seems to be that East Asian models certainly played a role in stimulating the emergence of Imagism, specifically the Japanese form that we now call the haiku. Therefore, despite Pound's well-known interest in Chinese poetry, any credit that China might claim for this breakthrough can only be accounted for as indirect, in that great haiku masters, such as Matsuo Bashō 松尾芭蕉 (1644-1694), were demonstrably admirers of Chinese literary culture (Qiu, 2005). On the other hand, the models long known in Japan of Tang verse, and the language in which their composition was discussed, can arguably be placed quite firmly in the remoter ancestry of Pound's great discovery, as we shall have occasion to note below. And what needs to be stressed is that for all Pound's 
infatuation with Confucianism, that language was most certainly in no small part originally Buddhist.

This fact in itself is no news at all. In James J. Y. Liu's classic, pioneering study, The Art of Chinese Poetry, long a staple of Chinese studies reading lists, he already noted that one of his own key terms, jingjie 境界, which he uses in the sense of the "world" created by a poet, derives proximately from Wang Guowei 王国维 (1877-1927), but also that originally it rendered into Chinese the Sanskrit term vișaya, meaning in Buddhist thought "sphere" or "spiritual domain" (Liu, 1962: 84, 91-100). The choice of alternative renderings here is no accident: by the end of the discussion here the reader will have about a couple of dozen or so different translations to choose from; to labour this point I have made no attempt to impose any unifying terminology of my own. Originally, no doubt, matters were fairly unambiguous: in pre-imperial China the expression meant a boundary, and hence as a first step its semantic range came to be extended quite naturally to indicate "territory." ${ }^{2}$ In Buddhist translations that extended meaning became more abstract, so that feiwo jingjie 非我境界 in the Longer Pure Land Sutra has been rendered into English as "not within the range of my abilities" (Gómez, 1996: 164). ${ }^{3}$ But this type of usage meant that the original compound term was further pressed into service most often in the abbreviated form of jing 境 alone - to express vișaya, used technically to represent the philosophical concept of "sensory object," to adopt one of the dozen translations used by Dan Lusthaus in rendering this evidently somewhat tricky element in Buddhist thought (2002: 55). ${ }^{4}$ His suggested philosophical renderings are by no means comprehensive: D. T. Suzuki offers for jingjie "individuation, external world, world of particulars," and no doubt even within a narrowly philosophical context the list could be further extended (Suzuki, 1930: 443). To make matters worse, a comprehensive list of all the Sanskrit equivalents that may lie behind jing and jingjie runs to 27 items in each case (Hirakawa, 1997: 302). The development towards the deployment of jing in philosophical writing was not solely Buddhist, since for example the Guo Xiang 郭象 commentary on Zhuangzi 庄子 of $300 \mathrm{CE}$ already speaks of shi fei zhi jing 是非之境, the "realm of right and wrong," and the like (Guo, 1961: 1A:102). But its involvement in discussion of matters of cognition does seem to be a characteristic of its use in translated Buddhist texts.

\footnotetext{
${ }^{2}$ Zhang Hua 張華 (232-300) demonstrates the ambiguity of the expression when he says, with regard to early China up to the end of the Spring and Autumn period, that zhuguo jingjie, quanya xiangru 诸国境界, 犬牙相入, for while the "boundaries of the kingdoms" can be said cartographically to have "intercut like [a row of] dog's teeth," it is in fact the territories that they bounded that did so (Fan, 1980: 1:7). Greatrex (1987: 71) translates judiciously as: "The territories and borders of the various states are as interlocked as a dog's teeth"; there is more in his n.6, p. 184 on the dog's teeth metaphor.

${ }^{3}$ For a translation of the equivalent Sanskrit as "I am not capable of understanding this wondrous array on my own," see Gómez (1996: 68).

${ }^{4}$ Elsewhere Lusthaus' translations of the term range across "circumstances" (2002: 1), "sensedobject" (2002: 121), "objects" (2002: 282), "cognitive object" (2002: 313, n.66), "sense-objects" (2002: 335), "external perceptual fields" (2002: 438), "perceptual field" or "perceptual object" (2002: 445, n.28), "cognitive object" (2002: 454), "mental objects" (2002: 460), and, finally, simply "things" (2002: 474).
} 
How could such a word end up as a literary term? Surely it could only have been a somewhat arbitrary borrowing whose meaning in poetry criticism can only be derived from the context in which it is used, without undue reference to its origins? Surely Tang poets were much more concerned with heavy drinking than mastering the intricacies of Buddhist phenomenology? For such, it seems to me, is rather the line taken in the most succinct and clear account in English of the introduction of the concept outlined by James Liu into the history of literary criticism in China. This may be found in a study by Yang Jingqing. The purpose of Yang's work is to question the common assumption that the poetry of Wang Wei 王维 (699-759) embodies the insights of Zen, or rather (to revert at this point the more appropriate Chinese pronunciation) Chan. This is certainly an argument well worth making: the word "Chan," as already noted, originally signified no more than "meditation," and though in the early eighth century many meditators had taken the first step towards forming a distinctive tradition by tracing their spiritual genealogy to the sixth century Indian patriarch Bodhidharma, there is no sign that they conceived of themselves and their particular groups as belonging to any overarching and distinctive school of Chinese Buddhism. Indeed, even in the ninth century one finds that the notion of a "Chan school" could still find room for meditators practising methods associated with the Tiantai 天台 tradition that had been formulated in the early seventh century (Kamata, 1971: 48; Broughton, 2009: 110). ${ }^{5}$ But while Yang's analysis gives due credit to Buddhist terms that had by Wang's time entered into discussions of Chinese literature, his aim is to stress the independence of poetic composition and Buddhist practice as two separate areas of endeavour. In challenging the details of Yang's account of Buddhism in relation to literary criticism there is no intention here of contradicting his overall thesis; it is simply that his concise summary affords a convenient starting point for the reconsideration of the role of a particular word in both Buddhist and literary thought and thereby illuminating the quest for an image as an aspect of Tang poetry.

The first passage Yang takes up concerning jing in relation to Wang Wei is one from the Shige 诗格, a work on poetics attributed to his contemporary and friend Wang Changling 王昌龄 (c. 698-755), a poet whose writing in the opinion of one later critic, Shi Buhua 施补华 (1835-1890), also exhibits a touch of Zen (Huang, 1981: 61). Striving for a fairly plain and literal version of this passage that avoids words such as "inspiration," entangling the Tang mind in too many European ideas, I would suggest for the quotation: "If the thought does not come, you must then let your feelings run free and let it be, so that a jing is born; only thereafter illumine them by means of the jing, then the thought will come, and then you compose your piece” 思若不來, 即须放情却寛之, 令境生。然后以境照之, 思则便來, 來即 作文. The translation for jing offered by Yang in his version of this passage is "scene" (Yang, 2007: 172). Wang Changling's authorship of these words seems much more certain than for other material allegedly from the Shige that has come down to us, and whoever wrote these words, they must be dated to the very early ninth century at the latest, since they are to be found in the Bunkyo hifu ron 文鏡秘府論, a guide to composition in Classical Chinese by a Japanese monk and visitor to China, Kūkai

\footnotetext{
5 Kamata here is reprinting Zongmi 宗密 (780-841), Chanyuan zhuquan ji duxu 禅源諸詮集都序 from a better edition than those used in standard canonical collections, such as Taishō Canon no. 2015, with annotation and a Japanese translation.
} 
空海 (774-835) (1975: 129 [section nan 南]). The exact date of his compilation is unclear, but its first drafting appears to have been some time before 820; it is worth noting too that it remained a work of importance, read for example by the aforementioned Matsuo Bashō (Abé, 1999: 480, n.96). A second quotation in Kūkai's guide from the same source on poetics takes a similar tack: "Whenever you make it your intention to write a poem you must first still your mind, and when the eye strikes on the right thing, then you must use your mind to strike it and deeply penetrate the jing” 夫置意作诗, 即须凝心, 目撃其物, 便以心撃之, 深穿其境. For this passage Yang cites a translation by Stephen Owen in which we find the rendering to be "world-scene [jing, perhaps 'environment']" (Kūkai, 1975: 129; Yang, 2007: 172; Owen, 1996: 123).

Yang's account of the material associated with Wang Changling then cites the usage of jing to be found in a work of scholastic Buddhist philosophy, elucidated by means of a dictionary of Buddhist terminology, and while conceding that Wang does show some familiarity with Buddhism in some of his verses, Yang concludes that "these pieces of information are not enough to justify the assumption that Wang Changling, in the Shige, was talking about poetry from a Buddhist point of view or introducing Buddhist doctrines into poetics" (Yang, 2007: 173-4). He then turns to the monk-poet Jiaoran 皎然 (730-799) and his treatise on writing poetry, Shishi 诗式, which contains a section on “obtaining jing" qujing 取境 - in fact in his final section Jiaoran returns to this topic, making it clear that it is the key to poetic composition (Yang, 2007: 175-6; Jiaoran, 1981: 31, 35). Here Yang concludes that, "in spite of the possible Buddhist connotations of the term jing, Jiaoran uses it in a fully literary context to refer to some kind of imagery formed in the mind before it is put into verse" (Yang, 2007: 176).

There are, in my view, a number of reasons for thinking that the dichotomy between literary and Buddhist thought here is a little overdrawn. First, the term jing is not confined to learned treatises on Buddhist phenomenology, but also plays a significant part in works on meditation, including works on meditation designed for beginners, rather than for monkish virtuosi in this practice. A good example would be in the basic introductory manual used by the Tiantai school (a reference to whose practice of meditation has already been made above), a guide so popular that it has been frequently translated into European languages - the early (1938) English version cited here is entitled "Dhyana for Beginners," though because it has been determined that the Chinese original has been modified since Tang times, reference is also made to a version of the text drawing on a critical edition established in Japan in 1954, and to a more recent translation by Bhikshu Dharmamitra that prints Chinese text on the facing page. Naturally, of course, tracing the translation of jing into English throughout such sources only serves to underline the problem of putting unfamiliar ideas into plain language.

Thus when we first encounter the statement in Goddard's 1938 translation that "there are six aspects of behaviour," as for example "regards eyes towards sights" and "ears towards sounds" and so forth, there is little indication that this list of six aspects begins in Chinese as 所言境者, 谓六塵境; closer is Dharmamitra's version: "As for what is referred to as 'objective conditions', it refers to six kinds of objective conditions" (Goddard, 1938: 469; Sekiguchi, 1974: 110; Dharmamitra, 2008: 
117). ${ }^{6}$ Later on, in discussing some of the hazards of meditation, the warning 或时见 种种诸异境界 is rendered variously as "sometimes there will be strange changing conditions," or "one might see all sorts of strange mental states" (Goddard, 1938: 481; Sekiguchi, 1974: 136; Dharmamitra, 2008: 149). "Conditions" generally seems to be the preferred way here of representing jing or jingjie when discussing the negative illusory images sometimes unleashed by meditation. Later in the text, however, mojing 魔境, which might be understood as the realm of Māra or delusion, becomes subsumed in the earlier English translation into the category "evil influences," in a deliberate, openly acknowledged attempt on the part of the earlier translator at ensuring that the existence of an actual King of Evil and his demons is not affirmed; more recently the term has been rendered a degree more explicitly as "demon states" (Goddard, 1938: 483, 486; Sekiguchi, 1974: 152; Dharmamitra, 2008: 163). Yet whatever phraseology we choose from among the many European language translations of this opuscule to convey the experience of meditation in Sui-Tang times - and it would be possible to add substantially to the examples already given - it is important to see that jing was not a term confined to book learning, but one that might also be encountered within the everyday activity of achieving mental discipline.

Secondly, moreover, in that this activity was not confined to the Buddhist clergy, we find that the terms jing and jingjie, even if originally associated with distinctively Buddhist approaches to cognition, turn up outside specifically Buddhist sources as well. It has been observed more than once that the basic training manual here entitled "Dhyana for Beginners" exerted an influence not only on other Buddhist meditators but also on Daoists. ${ }^{7}$ It is not surprising therefore to find that in the early eighth century Daoist text most closely allied to "Dhyana for Beginners" when it comes to discussing the interlinked notions of mind and of the "realm of delusion" the latter element is expressed with a rather similar term to mojing, namely huanjing 幻境, a compound which was in fact used by some Buddhist translators to render Māya-vișaya (Kohn, 1987: 87, and Chinese text 162.2a1; Suzuki, 1930: 317,431 ). Elsewhere in the same work, where the relationship with mind is again discussed, jing alone is translated by one scholar of Daoism as "projected reality" (Kohn, 1987: 103, and Chinese text 166.11a.17-19). It is possible that the notion of projection may not be appropriate, since no such process would appear to be clearly envisaged in the text, but the translator is at any rate right to point out that Daoists had incorporated jing into their vocabulary in their own way in the preceding century - in their sources of that period it was rendered by Isabelle Robinet into French as "objet," or (rendering a Chinese gloss in one influential Daoist treatise) "le monde" (Robinet, 1977: 245-6, 262-3). Another Daoist compendium of the same period contains no less than six passages discussing the relationship between the mind and jing (Zhu, 1989: 191-3). So, well before Kūkai, and even before Wang Changling, the deployment of this term was far from having been a Buddhist monopoly.

\footnotetext{
${ }^{6}$ The Chinese of the Dharmamitra translation is cross-referred to the electronic CBETA version of the Taisho Canon. Goddard did not know enough Chinese to translate by himself: the work was carried out by his friend the Chinese monk Waidao, acknowledged as "Bhikshu Wai-tao": see Aitken (1996: 9 n.7).

${ }^{7}$ For influence on the Daoist text consulted here, see Kamitsuka (1982: 234-5) and now also Kohn (2015). For its influence on the Chan tradition, see Bielefeldt (1986: 133-4).
} 
The third reason for seeing Buddhist and literary usage of the term jing as more overlapping than entirely separate is that eighth century Tang poets make use of it in their compositions. Of course, not every use of $j i n g$ in poetry can be situated in the vocabulary of mental discipline discussed so far. When for example Wang Changling uses the phrase renjing 人境 in one of his poems dedicated to a Buddhist monk - a phrase also used more than once by Du Fu 杜甫 - it would plainly be wrong to understand this as "people considered as objects of cognition" (Huang, 1981: 52; Hiraoka, 1964: no. 06752). The phrase is simply taken from the opening line of the fifth in the Tao Qian 陶潜 (365-427) series on “Drinking Wine" Yin Jiu 饮 酒 where - despite the efforts of later critics influenced by Jiaoran and his successors - the translation by Robert Kotewall and Norman L. Smith (for example) of 结庐在人境 as “I built my hut amid the throng of men" seems fair enough (Kotewall and Smith, 1962: 9; Gong, 1996: 219, 222). We might also disqualify a poem attributed to Dai Shulun 戴叔伦 (732-789) that uses the term huanjing, on the grounds that even if there is no doubt that it is a late eighth-century poem, it is also attributed to Qingjiang 清江 (?-?811), who was a monk poet who might therefore be expected to include some scriptural language in his verse (Quan Tang shi, 1960: 273:3091). ${ }^{8}$ But what about Li Qi 李颀, whose dates are unknown, but who, since he passed the jinshi 进士 examinations of 735, must count as a secular literary figure? He has a poem on the new brickwork of a well in a Luoyang monastery, “Changshou si Can gong yuan xin zhou jing” 长寿寺粲公院新甃井, which contains the line “The jingjie, dependent on the mind, is pure" 境界因心净 (Quan Tang shi, 1960: 134:1366; Hiraoka, 1964: no. 06404). ${ }^{9}$

Such cases may not be common, but there is a fourth argument for considering the use of jing in the Shige description of poetic composition to be more closely linked to Buddhism than at first might appear to be the case, and that concerns the linguistic context in which occurrences of the word are situated in the text, which strongly suggest a connection with meditation. Mental discipline in Tang China did not have to be discussed in the terminology of a technical manual like "Dhyana for Beginners", even if such works were not uncommon, but could in more literary contexts call on a very ancient vocabulary that raised no particular sectarian connotations. Wang Changling, for example, refers twice in his slim surviving corpus of poems to "fasting the mind" zhaixin 齋心, a classical description for mental discipline that we find by the early years of the ninth century accepted not only by Buddhists and Daoists but also by some who wished to assert a purely Confucian identity (Huang, 1981: 28, 80; Hiraoka, 1964: no. 06713 and 06816; Barrett, 1992: 113). Turning back to the early Japanese quotations of Wang's Shige already cited above, the words zhao 照 (“illumine"), in the first passage and ning 凝 ("still," or literally "freeze"), in the second both fall into this same category. Though it would take a much more extended essay to do them full justice, we may cite just one

\footnotetext{
8 “Song che canjun Jiangling” 送車参軍江陵, poem no. 14407 in Hiraoka (1964), also included as no. 44328: the poem is already listed twice under the two names in the late tenth century Wenyuan yinghua 文苑英华, though whether the note there in printed editions pointing out the problem is attributable to the original editors I do not know - there are a couple of other Dai Shulun poems also attributed to Qingjiang in Quan Tang shi 全唐诗.

${ }^{9}$ This poem was as far as I am aware first printed in movable type in the early-to-mid-sixteenth century; see Tang wushi jia shiji (1989: 151c).
} 
example of a source that employs both words, the late eighth century Baozang lun 宝藏論, a Buddhist work that draws on Tang Daoist ideas, which uses zhao to affirm that spiritual power is "to illuminate things with a still mind" 静心照物, and uses ning to say that those who understand inherent transcendence "find stillness and quiescence in their present existence” 當體而凝寂 (Sharf, 2002: 33-6, 205, 220). The two characters also form part of the sixteen-character credo that, in the view of Hu Shi 胡适 (1891-1962), encapsulated the meditation techniques of the Northern School of Chan, at least as described in the writings of their rivals in the Southern School (Yanagida, 1975: 294; Hu, 1970: 287; Gernet, 1977: 93, 94 n.15). In the past it seems to have been assumed by many that such language in Tang poetry and literary criticism is merely decorative. This may not necessarily be the case, and some further consideration of this matter might be worthwhile.

But for the final argument for seeing the literary term jing as strongly linked to the Buddhist practice of meditation we must turn to an explicit statement on the matter from a contemporary of Kūkai whose significance for the history of East Asian literary thought has in the past been less appreciated, namely Liu Yuxi 劉禹锡 (772-842). Recently, however, Anthony DeBlasi has translated a portion of an extended preface to a poem of parting written for a Buddhist monk-poet in which Liu makes clear his thoughts on the relationship between Buddhism and literature (DeBlasi, 2002: 107). ${ }^{10}$ This opening passage of the preface explains that monks empty their hearts of desire, allowing “scenes" jing 景 (or in the version of the text cited here, "images" xiang 象) to enter, which spill out in words, which find literary form - such is the reason for the emergence of so many monk poets. But in next summarising this process, Liu then condenses the first part of his account into the succinct dictum 因定而得境 “through meditation they obtain jing” (Quan Tang shi, 1960: 357:4015; Hiraoka, 1964: no. 18758). This as a statement seems clear enough.

Exactly what it means, however, is quite another matter, as much part of the study of psychology as of literary history. One possible hint comes from another theme noticed by Stephen Owen in the material preserved by Kükai, in which it is recommended that the poet seeking a poetic conception ( $y i$ 意) should try going to sleep (Owen, 1996: 111-12, 114). ${ }^{11}$ This strongly suggests that what was valued as a result of this particular technique was what we now call hypnagogic experiences and what meditation manuals like "Dhyana for Beginners" also offered was the experience of unbidden images. Otherwise, if the poet has to hunt through everyday reality for these things, they become, in the terminology of Stephen Owen's discussion, "trouvailles", or lucky finds - like Ezra Pound's experience in the Paris Metro (Owen, 1996: 108, 111, 120-21). Such interruptions in the course of the mundane may indeed connect with another element in poetic composition to which a glancing allusion has already been made above: if many of the poems of parting that bulk out the Tang literary heritage were written when drunk, then we should recall that it was a level of inebriation that James Liu - before he came to consider

\footnotetext{
${ }^{10}$ DeBlasi here is concerned not with poetic creativity, but rather with the moral problem of detachment, though the two in Liu's mind seem to have been interconnected.

11 It goes without saying that this was not a specifically Buddhist practice; it does however give us a clue as to what was appreciated in Buddhist practice also.
} 
the phrase a little too precious - was disposed to translate as "rapture with wine" (Liu, 1962: 58-60).

The predominance of this particular form of rapture, of course, posed a problem for the monk poet, to whom it was taboo: "rapture with tea" does not sound quite so alluring, though there is every sign that the Buddhists did their best to draw attention to its rival attractions. ${ }^{12}$ By contrast, to promote meditation as an adjunct to creativity looks more like a natural development of existing trends. Buddhism in all its forms emphasises aspects of cognition, so that there is substantial evidence that by the sixth century CE in China it was influencing the way that poets looked at the world (Tian, 2007: 211-59). This is not to deny that the adjunct to creativity provided by religious practice was seen by lay poets at least as anything other than a borrowing from another field of experience: Liu Yuxi, at any rate, speaks elsewhere of poetic exaltation and Buddhist enlightenment as two separate, antithetical things; similarly for his friend Bai Juyi 白居易 (772-846) meditation and drinking are also seen as antithetical. ${ }^{13}$ In a couplet of obscure derivation attributed to the late Tang poet Zhou Pu 周朴 (d. 879) in praise of the famous Chan master Lingyou 靈祐 (771-853), he describes the master as a meditator, himself as a poet and the Tang emperor as a third among individuals unique in their respective roles, suggesting again a conceptualisation of meditation and poetry as co-equal domains (Quan Tang shi, 1960: 673:7704). ${ }^{14}$

Such evidence thus suggests that we should be cautious not to ascribe anything more than a touch of Zen to late Tang poets - and quite possibly many of them remained entirely untouched at that. But the evidence does show something else at the same time. The interest of poets in meditation formed a significant part of a broader curiosity about the origin of unbidden images within the mentality of perception that caused them to reflect upon and to discuss the topic. In that sense it may be said with only a little exaggeration that the poets of the age were all imagists, and that the later tradition in East Asia continued to bear the imprint of their preoccupations.

For the English-language poetic tradition the groundbreaking work of Ezra Pound certainly serves as a point of comparison. Whether Pound also represents a point of contact is less clear, though since his epiphany took place in Paris a full examination of that topic would no doubt lead into the investigation of possible

\footnotetext{
12 This is now extensively documented in Benn (2015); in particular p. 69 includes the phrase "drunk on tea" in relation to artistic creativity in a non-Buddhist context, and see also his p. 84 for the poem by Liu Yuxi prefaced by the remarks on meditation and jing discussed above.

${ }^{13}$ See, respectively, “Chou letian zuihou kuangyin shiyun” 酬乐天醉后狂吟十韻 in which we find these lines: 诗家登逸品, 释氏悟真鉒 (Quan Tang shi, 1960: 362:4093; Hiraoka,1964: no. 19125); and “He zhifei” 和知非 in which we find the following: 禅能泯人我, 醉可忘荣悴 (Quan Tang shi, 1960: 445:4987; Hiraoka, 1964: no. 23208).

14 禅是大潙诗是朴, 大唐天子只三人. Although in Quan Tang shi (1960: 673:7696) we find another poem dedicated to Lingyu (Hiraoka, 1964: no. 37192), the attribution of which to Zhou is already attested in the tenth century, how this random couplet came to be preserved, attached with others to his surviving works, is unknown to me. By this point, as one reader of an earlier version of this piece has pertinently noted, the picture of Buddhism and Tang poetics is complicated by the influence of the ex-monk Jia Dao 贾岛 (779-843), though his later impact in Japan was perhaps limited - the whole question is too complex to consider here.
} 
French intermediaries, such as Marquis D'Hervey-Saint-Denys (1822-1892), pioneer oneirologist and translator of Tang poetry, or Paul-Louis Couchoud (1879-1959), an early translator of haiku. ${ }^{15}$ Even in the twenty-first century the probable French background to the achievement embodied in "In a Station of the Metro" still seems not to have attracted the attention of Anglophone writers on Pound, despite the fact that even the most preliminary survey of the spread of an awareness of haiku lists several French studies and translations of this type of poem that antedate Pound's 1911 composition (Brower, 1972: 109-113). ${ }^{16}$ Most interestingly, Angus Graham, who had argued strongly for Japanese influences on Imagism in his original Poems of the Late T'ang, and mentions the work of Couchoud, in returning to the question once more in the "Additional Preface" to his Penguin republication in 1977, points to fresh research that had pushed back an explicit admiration for Japanese poetry acknowledged by the eventual imagist and student of French poetry F. S. Flint (1885-1960) as early as 1908 (Graham, 2008: 12, 16).

But whatever the precise connection, Pound's notion of the "image," while no doubt encouraging translators to ignore the formal sophistication of Tang verse, did at last allow the Chinese tradition to speak to the reader of English in a way that by the late nineteenth century the Japanese tradition was also doing. A frog jumping into a pond, or better still, a great wave breaking at its crest - these images speak across cultures with an immediacy that overcomes linguistic barriers for the reasons explored above: we should not be surprised if such possibilities for transcultural communication lie, too, within the legacy of the Tang poets.

\section{References}

Abé, Ryūichi (1999), The Weaving of Mantra: Kükai and the Construction of Esoteric Buddhist Discourse, New York: Columbia University Press.

Aitken, Robert (1996), "The Christian-Buddhist life and works of Dwight Goddard," Buddhist-Christian Studies 16: 3-10.

Barnes, Archie (2007), Chinese Through Poetry: An Introduction to the Language and Imagery of Traditional Verse, London: WritersPrintShop.

Barrett, T. H. (1992), Li Ao: Buddhist, Taoist, or Neo-Confucian? Oxford: Oxford University Press.

---(2009), "The advent of the Buddhist conception of religion and its consequences for the analysis of Daoism," Sungkyun Journal of East Asian Studies 9 (2): 149-165.

---(2015), "Poetry: China (until the Song period)," in Brill's Encyclopedia of Buddhism, Jonathan A. Silk, ed., vol. 1, 541-546, Leiden: Brill.

\footnotetext{
${ }^{15}$ The only study I have seen on the marquis as translator, Pino and Rabut (1999), does not concern his poetry; Kenner (1971: 184) mentions Pound's acknowledgment of Japanese influence but does not explore the matter. We should perhaps also bear in mind possible direct Chinese influence from the translation work of Judith Gautier (1845-1917), for whom see Yu (2007). ${ }^{16}$ Nader (2015: 11-22), in exploring Pound's knowledge of China as accumulated in the USA and London prior to his introduction to the work of Ernest Fenollosa in 1913, on p. 16 notes that he was reading Confucian texts in French, but does not mention Japanese literature.
} 
Benn, James (2015), Tea in China: A Religious and Cultural History, Honolulu: University of Hawai'i Press.

Bielefeldt, Carl (1986), “Ch'ang-lu Tsung-tse's Tso-ch'an I and the 'secret' of Zen meditation," in Peter N. Gregory, ed., Traditions of Meditation in Chinese Buddhism, 129-161, Honolulu: University of Hawai'i Press.

Broughton, Jeffrey Lyle (2009), Zongmi on Chan, New York: Columbia University Press.

Brower, Gary L. (1972), Haiku in Western Languages: An Annotated Bibliography (With Some Reference to Senryu), Metuchen, New Jersey: The Scarecrow Press.

Bullock, Michael, and Jerome Ch'ên, Poems of Solitude, London: Lund Humphries, 1960.

Chang, H. C. (1977), Chinese Literature 2: Nature Poetry, Edinburgh: Edinburgh University Press.

DeBlasi, Anthony (2002), Reform in the Balance: The Defense of Literary Culture in Mid-Tang China, Albany, NY: State University of New York Press.

Dharmamitra, Bhikshu, trans. (2008), The Essentials of Buddhist Meditation, Seattle: Kalavinka Press.

Fan Ning 范寧, ed. (1980), Bowu zhi jiaozhu 博物志校證 (Annotated Edition of the Record of Diverse Matters), Beijing: Zhonghua shuju.

Gernet, Jacques (1977), Entretiens du Maître de Dhyâna Chen-houei du Ho-tsö, Paris: EFEO.

Goddard, Dwight (1938), A Buddhist Bible, Thetford, Vermont: Dwight Goddard.

Gómez, Luis O. (1996), The Land of Bliss: The Paradise of the Buddha of Measureless Light, Honolulu: University of Hawai'i Press.

Gong Bin 龚斌, ed. (1996), Tao Yuanming ji jiaojian 陶渊明集校笺 (Annotated Works of Tao Yuanming), Shanghai: Shanghai guji chubanshe.

Graham, A. C. (2008), Poems of the Late T'ang, New York: New York Review of Books.

Greatrex, Roger (1987), The Bowu zhi: An Annotated Translation, Täby, Stockholm: Akademitryk AB.

Greene, Eric M. (2016), "Visions and visualizations in fifth-century Chinese Buddhism and nineteenth-century experimental psychology," History of Religions 55 (3): 289-328

Guo Qingfan 郭慶藩 (1961), Zhuangzi jishi 荘子集释 (Collected Commentaries to Zhuangzi), Beijing: Zhonghua shuju.

Hawkes, David (2016), A Little Primer of Tu Fu, Hong Kong: Chinese University of Hong Kong Press.

Hirakawa, Akira (1997), A Buddhist Chinese-Sanskrit Dictionary, Tokyo: The Reiyukai.

Hiraoka Takeo 平岡武夫 et al., comp. (1964), Tōdai no shihen 唐代の詩篇 (Compilation of Tang Poems), Kyoto: Daigaku Jinbun Kagaku Kenkyūjo.

Hobson, Peter (2003), Poems of Hanshan, Walnut Creek, CA: AltaMira.

Hu Shi 胡适, ed. (1970), Shenhui heshang yiji 神會和尚遗集 (Collected Works of Master Shenhui), Taipei: Hu Shi jinian guan.

Hu Zhenheng 胡震亨 (1981), Tangyin guiqian 唐音癸籤 (Notes on Tang Poetry), Shanghai: Shanghai guji chubanshe.

Huang Ming 黄明, ed. (1981), Wang Changling shiji 王昌龄诗集 (Collected Poems of Wang Changling), Nanchang: Jiangxi renmin chubanshe. 
Jiaoran 佼然 (1981), “Shishi” 诗式 (Poetical Form), in He Wenhuan 何文焕 (17321809), comp., Lidai shihua 历代诗话 (Remarks on Poetry Through the Ages), 25-36, Beijing: Zhonghua shuju.

Kamata Shigeo 鎌田茂雄, trans. (1971), Zengen shosen shū tojo 禅源諸詮集都序 (General Preface to Collected Writings on the Sources of Chan), Tokyo: Chikuma shobō.

Kamitsuka Yoshiko 神塚淑子 (1982), “Shiba Shōtei Zabōron ni tsuite” 司馬承禎「坐 忘論」について (On Sima Chengzhen's Sitting in Oblivion), Tōyō bunka 東洋 文化 62: 213-242.

Kenner, Hugh (1971), The Pound Era, Berkeley: University of California Press.

Kohn, Livia (1987), Seven Steps to the Tao: Sima Chengzhen's Zuowang lun, Nettetal: Steyler Verlag.

Kohn, Livia (2015), "The Daoist Adaptation of Buddhist Insight Meditation," in Halvor Eifring, ed., Meditation and Culture: The Interplay of Practice and Content, 11-23, London: Bloomsbury.

Kotewall, Robert, and Norman L. Smith (1962), The Penguin Book of Chinese Verse, Harmondsworth, Middlesex: Penguin Books.

Kūkai 空海, comp. (1975), Bunkyō hifu ron 文鏡秘府論 (Mirrors of Literature: Treatises of the Secret Treasury), Zhou Weide 周维德, ed., Beijing: Renmin wenxue chubanshe.

Liu, James J. Y. (1962), The Art of Chinese Poetry, Chicago: The University of Chicago Press.

Liu Shaoling 刘晓玲 (2016), Dunhuang sengshi yanjiu 敦煌僧诗研究 (Research on Dunhuang Monastic Poetry), Beijing: Zhongguo shehui kexue chubanshe.

Lusthaus, Dan (2002), Buddhist Phenomenology, London: RoutledgeCurzon.

Lyssenko, Nicolas, and Delphine Weulersse (1986), Poésie Tang: Quatrains de Cinq Pieds, Paris: Editions Lyssenko.

McMullen, David (2013), "Boats Moored and Unmoored: Reflections on the Dunhuang Manuscripts of Gao Shi's Verse," Harvard Journal of Asiatic Studies 73 (1): 83-145.

Nader, Ira (2015), Cathay: Ezra Pound's Orient, Melbourne: Penguin Australia.

Nielson, Thomas P. (1972), The T'ang Poet-Monk Chiao-jan, Tempe, Arizona: Center for Asian Studies, Arizona State University.

Owen, Stephen (1996), The End of the Chinese "Middle Ages": Essays in Mid-Tang Literary Culture, Stanford: Stanford University Press.

Pimpaneau, Jacques (2004), Lettre à une jeune fille qui voudrait partir en Chine, Arles: Philippe Picquier.

Pino, Angel, and Isabelle Rabut (1999), “Le marquis D'Hervey-Saint-Denys et les traductions littéraires. A propos d'un texte traduit par lui et retraduit par d'autres," in Viviane Alleton and Michael Lackner, eds., De l'un au Multiple. Traductions du Chinois Vers les Langues Européennes, 114-142, Paris: Éditions de la Maison des sciences de l'homme.

Pulleyblank, E. G. (1978), "Linguistic Evidence for the Date of Han-shan", in Ronald Miao, ed., Studies in Chinese Poetry and Poetics, 163-195, San Francisco: Chinese Materials Center.

Qiu Peipei (2005), Bashō and the Dao: The Zhuangzi and the Transformation of Haikai, Honolulu: University of Hawai'i Press.

Quan Tang shi 全唐诗 (Complete Tang Poems) (1960), Peng Dingqiu 彭定求 (16451719), ed., Beijing: Zhonghua shuju. 
Robinet, Isabelle (1977), Les Commentaires du Tao Tö King, Paris: Collège de France, IHEC.

Robinson, G. W. (1973), Wang Wei: Poems, Harmondsworth, Middlesex: Penguin Books.

Sekiguchi, Shindai 関口真大 (1974), Tendai Shō Shikan 天台小止観 (Shorter Tiantai Calming and Insight), Tokyo: Iwanami shoten.

Sharf, Robert H. (2002) Coming to Terms with Chinese Buddhism, Honolulu: University of Hawai'i Press.

Suzuki, D. T. (1930), Studies in the Lankavatara Sutra, London: Routledge Kegan Paul.

Tang wushi jia shiji 唐五十家诗集 (Fifty Collections of Tang poems) (1989), Xu Jin 徐 缙 (1482-1548), ed., Shanghai: Shanghai guji chubanshe.

Tian, Xiaofei (2007), Beacon Fire and Shooting Star: The Literary Culture of the Liang, Cambridge, MA: Harvard University Press.

Twitchett, Denis (1989), “Po Chü-i's 'Government Ox'”, T'ang Studies 7: 23-38.

Waley, Arthur (1949), The Life and Times of Po Chü-i, London: George Allen \& Unwin.

Wang Lina 王丽娜 (2016), Hanyi Fodian jiesong yanjiu 汉译佛典偈颂研究 (Research on Buddhist Verse in Chinese Translations of Sutras), Beijing: Shangwu yinshuguan.

Williams, N. M. (2013). "The Taste of the Ocean: Jiaoran's Theory of Poetry," Tang Studies 31: 1-27.

- - (2017). "Quasi-Phantasmal Flowers: An Aspect of Wang Wei's Mahayana Poetics," Chinese Literature: Essays, Articles, Reviews 39: 27-54.

Xiao Lihua 萧丽华 (2013), Cong Wang Wei dao Su Shi: Shige yu chanxue jiaohui de huangjin shidai 从王维到苏轼: 诗歌与禅学交会的黄金时代 (From Wang Wei to Su Shi: The Golden Age of Interaction between Poetry and Chan Studies), Tianjin: Tianjin jiaoyu chuban she.

Yanagida Seizan 桝田聖山, ed. (1975), Ko Teki Zengaku an 胡適襌學案 (Hu Shi's Studies on Chan), Taipei: Zhengzhong shuju.

Yang, Jingqing (2007), The Chan Interpretations of Wang Wei's Poetry: A Critical Review, Hong Kong: The Chinese University Press.

Yu, Pauline (2007), "'Your alabaster in this porcelain': Judith Gautier's Le livre de jade", PMLA 122 (2): 464-482.

Zhu Senpu 朱森溥, ed. (1989), Xuanzhu lu jiaoshi 玄珠錄校释 (Collation and Annotation of the Record of the Mysterious Pearl), Chengdu: Bashu shushe. 